Brit. Heart F., 1967, 29, 616.

\title{
Potassium, Glucose, and Insulin in Treatment of Myocardial Infarction.
}

\author{
B. MITTRA* \\ From the Department of Medicine, Queen's University, and the Royal Victoria Hospital, Belfast 12
}

A simple form of treatment involving the administration of insulin subcutaneously, with glucose and potassium orally, has been shown, in a statistically controlled sequential trial, to lower the mortality in patients admitted to hospital after myocardial infarction (Mittra, 1965). Since that trial ended in June 1965, all patients admitted to a 50-bed general medical unit at the Royal Victoria Hospital, Belfast, with a diagnosis of myocardial infarction have been treated with this regimen. At the beginning of September 1966, the patients thus treated numbered 200. The results obtained in the post-trial period and their comparison with those obtained during the trial form the subject of this report.

\section{Clinical Material and Methods}

Only those patients in whom the diagnosis of myocardial infarction could be confirmed were included in this study. The diagnosis was considered to be established if $Q$ waves of pathological significance appeared on the cardiogram accompanied by an elevation of the $S-T$ segment and a later inversion of the $T$ wave, or if there were changes in the $S-T$ segment and $T$ wave suggestive of infarction, or there was bundle-branch block, accompanied by a significant and transient increase in serum glutamic oxaloacetic transaminase

Received October 7, 1966.

$\star$ Present address: The General Hospital, Sunderland, Co. Durham. (over 60 units) and/or serum lactic dehydrogenase (over 400 units). No selection was exercised with regard to age, sex, severity of illness, or presence of any complications. Six patients (four with severe cardiogenic shock, one with cardiac failure, and one with complete heart block and Stokes-Adams syncope), who died within a few hours of admission without receiving the regimen because urgent resuscitative measures were being applied instead, and three patients who died 8, 14, and 27 days after cessation of the regimen, respectively, were included in the final analysis. Mortality was assessed at the end of patients' stay in hospital, which varied from 3 to 6 weeks.

Patients received 10 units of soluble insulin immediately on admission and thereafter twice a day at $7.30 \mathrm{a} . \mathrm{m}$. and 5.30 p.m., 8-12 tablets (52-78 $\mathrm{mEq})$ of effervescent potassium (B.P.C.) in four divided doses a day, and 160 g. glucose orally, divided equally between two 6-hour periods following each injection of insulin. A higher intake of glucose, $240 \mathrm{~g}$. daily, which was advocated previously (Mittra, 1965), has not been found necessary in the later experiments. This treatment was given for a fortnight and then stopped. Of the 200 patients, 6, who were either unable to take the oral regimen or had serious arrhythmias, were given insulin, glucose, and potassium intravenously as a mixture containing 10 units soluble insulin and $20 \mathrm{mEq}$ potassium chloride in $500 \mathrm{ml}$. 10 per cent dextrose. Between 1.5 and 2 litres of this solution was given daily at a rate of 40-60 drops a minute, for a period of two to four days; thereafter the oral regimen was followed for another 10 to 12 days to bring the total up to 14 days.

TABLE

STANDARD FATALITY RATES BY AGE AND SEX

\begin{tabular}{|c|c|c|c|c|c|c|c|c|c|c|c|}
\hline & & & & \multicolumn{2}{|c|}{-39} & \multicolumn{2}{|c|}{$40-44$} & \multicolumn{2}{|c|}{$45-49$} & \multicolumn{2}{|c|}{$50-54$} \\
\hline & & & & $\mathbf{M}$ & F & $\mathbf{M}$ & $\mathbf{F}$ & $\mathbf{M}$ & $\mathrm{F}$ & $\mathbf{M}$ & $\mathbf{F}$ \\
\hline Fatality rates & .. & .. & .. & $0 \cdot 131$ & 0 & 0.2 & $0 \cdot 125$ & $0 \cdot 141$ & 0.357 & 0.227 & 0.235 \\
\hline
\end{tabular}


TABLE II

DETAILS OF AGE, SEX, AND MORTALITY OF PATIENTS IN THE TRIAL AND POST-TRIAL SERIES

\begin{tabular}{|c|c|c|c|c|c|c|c|c|c|c|c|c|c|}
\hline & \multicolumn{4}{|c|}{ Men } & \multicolumn{4}{|c|}{ Women } & \multicolumn{5}{|c|}{ Total } \\
\hline & $\begin{array}{l}\text { Total } \\
\text { No. }\end{array}$ & $\begin{array}{c}\text { Average } \\
\text { age } \\
\text { (yr.) }\end{array}$ & $\begin{array}{l}\text { No. of } \\
\text { deaths }\end{array}$ & $\begin{array}{c}\text { Mor- } \\
\text { tality } \\
(\%)\end{array}$ & $\begin{array}{c}\text { Total } \\
\text { No. }\end{array}$ & $\begin{array}{c}\text { Average } \\
\text { age } \\
\text { (yr.) }\end{array}$ & $\begin{array}{l}\text { No. of } \\
\text { deaths }\end{array}$ & $\begin{array}{c}\text { Mor- } \\
\text { tality } \\
(\%)\end{array}$ & $\begin{array}{c}\text { No. of } \\
\text { patients }\end{array}$ & $\begin{array}{c}\text { Average } \\
\text { age } \\
\text { (yr.) } \\
\end{array}$ & $\begin{array}{l}\text { Male: } \\
\text { female } \\
\text { ratio }\end{array}$ & $\begin{array}{l}\text { No. of } \\
\text { deaths }\end{array}$ & $\begin{array}{c}\text { Mor- } \\
\text { tality } \\
(\%)\end{array}$ \\
\hline $\begin{array}{l}\text { Clinical trial: } \\
\text { Control } \\
\text { Treated (ali } \\
\text { Post-trial (all } \\
\text { treated) }\end{array}$ & $\begin{array}{r}62 \\
62 \\
140\end{array}$ & $\begin{array}{l}58 \cdot 4 \\
60 \\
60 \cdot 5\end{array}$ & $\begin{array}{r}23(14) \\
6(4) \\
20(13)\end{array}$ & $\begin{array}{l}37 \\
9 \cdot 7 \\
14 \cdot 3\end{array}$ & $\begin{array}{l}23 \\
23 \\
60\end{array}$ & $\begin{array}{l}62 \cdot 1 \\
63 \cdot 2 \\
65\end{array}$ & $\begin{array}{r}7(5) \\
8(5) \\
15(7)\end{array}$ & $\begin{array}{l}30 \cdot 4 \\
34 \cdot 8\end{array}$ & $\begin{array}{l}85 \\
85\end{array}$ & $\begin{array}{l}59.4 \\
60.9\end{array}$ & $\begin{array}{l}2 \cdot 7: 1 \\
2 \cdot 7: 1 \\
2 \cdot 3: 1\end{array}$ & $\begin{array}{l}30(19) \\
14(9) \\
35(20)\end{array}$ & $\begin{array}{l}35 \cdot 3 \\
16 \cdot 5\end{array}$ \\
\hline
\end{tabular}

Figures in parentheses denote number with post-mortem examination.

The records of 1084 patients, 773 men and 311 women, with proven myocardial infarction (diagnosed according to the criteria used for inclusion of cases in this study but without enzyme estimations in the earlier years), who were admitted to the same 50-bed unit at the Royal Victoria Hospital, Belfast, from 1952-1964, were analysed to show the fatality rates by age and sex. Study of the fatality rates by separate years showed a high measure of consistency so that it was considered justifiable to draw up actuarial tables from these data (Table I), from which the probability of death in any patient with myocardial infarction in a given age and sex group could be estimated. The expected number of deaths in the trial and post-trial series was thus calculated and then compared with the number of deaths observed.

All the deaths in the trial and post-trial series were classified according to the various causes in order to detect any selective effect of the regimen. A patient's death was ascribed to cardiogenic shock, cardiac failure, or other miscellaneous causes such as cerebrovascular accident, rupture of the ventricle, or respiratory failure, when these conditions were present in severe form and persisted until death. The accompanying arrhythmias were ignored in this context. When a patient, who was otherwise reasonably well and progressing satisfactorily, died suddenly, arrhythmia was taken to be responsible for the death if the causative rhythm disorder was documented, or if no other cause of death could be found at necropsy.

Other medication was avoided as far as possible, but drugs such as digitalis, quinidine, diuretics, and vasopressors were given when necessary. None of the patients in the post-trial series received anticoagulant therapy, though this had been given to all the patients in the trial.

\section{RESULTS}

The over-all mortality in the post-trial series of 200 patients was 17.5 per cent which is similar to the 16.5 per cent mortality observed in the treated group of the trial. This was so in spite of the fact that patients in the post-trial series were slightly older and there were proportionately more women than men in this group when compared with the control and treated groups of the trial (see Table II).

Comparison of the expected number of deaths, derived from the standard fatality rate (Table I), with the number of deaths observed in all the groups, is shown in Table III. Although the number of deaths observed among men of the control group was slightly in excess of the expected number of deaths, the difference was statistically not significant (Table IV). Good agreement was obtained between the expected and observed number of deaths among women of the control group. There were marked differences between the expected and observed number of deaths in men and smaller differences in women among the treated patients of the trial and post-trial series. Statistical analysis (Table IV) showed that the reduction in mortality in men was highly significant whereas it was not significant in women.

The classification of all the deaths according to various causes is given in Table V. For the sake of simplicity the causes were regrouped into (1) arrhythmias, and (2) all other causes. In addition, all treated patients ( 85 in the trial and 200 in the post-trial series, making a total of 285) were con-

OF 1084 PATIENTS WITH MYOCARDIAL INFARCTION (1952-64)

\begin{tabular}{|c|c|c|c|c|c|c|c|c|c|c|c|}
\hline \multicolumn{2}{|c|}{ 55-59 } & \multicolumn{2}{|c|}{$60-64$} & \multicolumn{2}{|c|}{$65-69$} & \multicolumn{2}{|c|}{$70-74$} & \multicolumn{2}{|c|}{$75-79$} & \multicolumn{2}{|c|}{$80+$} \\
\hline $\mathbf{M}$ & $\mathbb{F}$ & $\mathbf{M}$ & $\mathbf{F}$ & $\mathbf{M}$ & $\mathbf{F}$ & $\mathbf{M}$ & $\mathbf{F}$ & $\mathbf{M}$ & $\mathbf{F}$ & $\mathbf{M}$ & F \\
\hline 0.221 & 0.235 & $0 \cdot 31$ & 0.304 & 0.417 & 0.278 & 0.394 & 0.471 & 0.486 & 0.5 & 0.462 & 0.647 \\
\hline
\end{tabular}


TABLE III

COMPARISON OF OBSERVED AND EXPECTED NUMBER OF DEATHS IN THE TRIAL AND POST-TRIAL SERIES

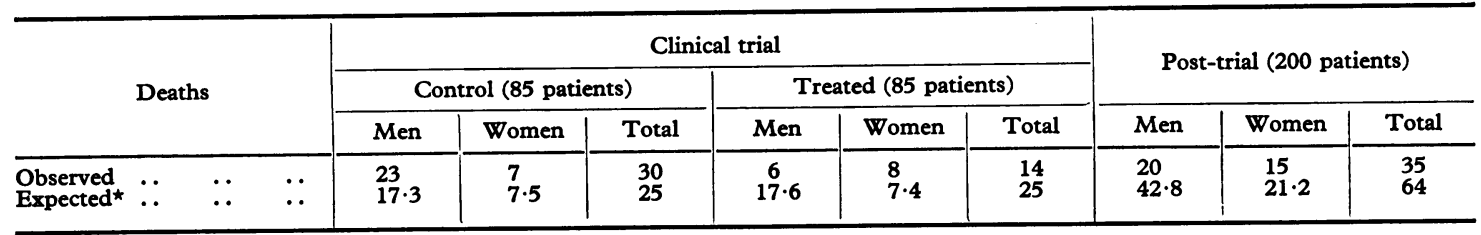

^ As derived from Standard Fatality Rate Table I.

TABLE IV

STATISTICAL COMPARISONS BETWEEN THE OBSERVED AND EXPECTED NUMBER OF DEATHS IN THE TRIAL AND POST-TRIAL SERIES

\begin{tabular}{|c|c|c|c|c|c|c|c|c|c|c|}
\hline & & & \multicolumn{6}{|c|}{ Expected vs. observed deaths } & \multirow{2}{*}{\multicolumn{2}{|c|}{$\begin{array}{c}\text { Observed deaths in } \\
\text { clinical trial }\end{array}$}} \\
\hline & & & \multicolumn{4}{|c|}{ Clinical trial } & \multirow{2}{*}{\multicolumn{2}{|c|}{ Post-trial series }} & & \\
\hline & & & \multicolumn{2}{|c|}{ Control } & \multicolumn{2}{|c|}{ Treated } & & & & \\
\hline & & & $x^{2}$ for 1 d.f. & $\mathbf{p}$ & $x^{2}$ for 1 d.f. & $\mathbf{p}$ & $x^{2}$ for 1 d.f. & $\mathbf{p}$ & $x^{2}$ for 1 d.f. & $\mathbf{p}$ \\
\hline \multirow[t]{2}{*}{$\begin{array}{l}\text { Men... } \\
\text { Women }\end{array}$} & .. & 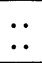 & $\begin{array}{l}1.32 \\
0.01\end{array}$ & $\begin{array}{l}>0.2 \\
>0.9\end{array}$ & $\begin{array}{l}7 \cdot 04 \\
0 \cdot 04\end{array}$ & $\begin{array}{l}<0.01 \\
>0.8\end{array}$ & $\begin{array}{r}10.83 \\
1.43\end{array}$ & $\begin{array}{l}<0.001 \\
>0.2\end{array}$ & $\begin{array}{c}13 \cdot 0 \\
0\end{array}$ & $\begin{array}{c}<0.001 \\
0\end{array}$ \\
\hline & Total & . & 0.68 & $>0.3$ & $4 \cdot 02$ & $<0.05$ & $11 \cdot 3$ & $<0.001$ & $7 \cdot 85$ & $<0.01$ \\
\hline
\end{tabular}

TABLE V

CAUSES OF DEATH IN THE TRIAL AND POST-TRIAL SERIES

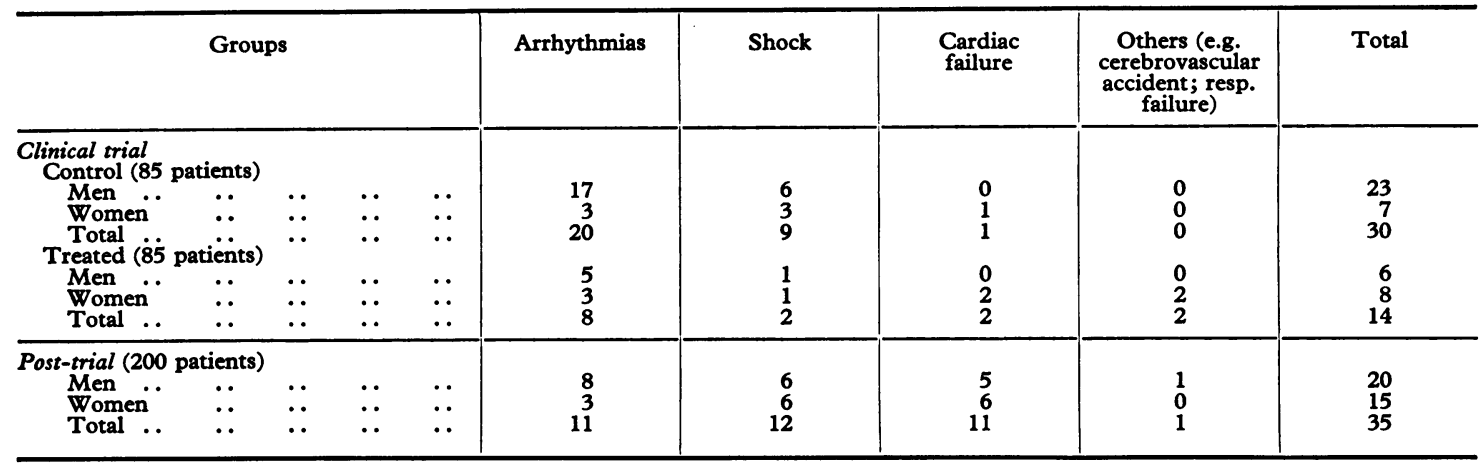

sidered in one group and compared with the controls (Table VI). The ratio of deaths due to arrhythmias to those due to other causes was $2: 1$ in the control group. In contrast, the ratio of deaths due to arrhythmias to those due to other causes was 2:3 among treated patients. The differences were statistically significant $\left(\chi^{2}\right.$ for 1 degree of freedom $=5.813 ; \mathrm{p}<0.02$ ).

The relation of the two sexes in either group with various causes of death is given in Table V. In the women in the control group, deaths due to arrhythmias were less frequent than those due to other causes, whereas among the men there were nearly three times as many deaths due to arrhythmias as deaths due to other causes. In the treated group the number of deaths due to arrhythmias was fewer in both sexes, despite the fact that the number of patients at risk was much greater than in the control group.

\section{Discussion}

The results obtained during the clinical trial have since been confirmed in the post-trial period as almost identical fatality rates were observed among 
Potassium, Glucose, and Insulin in the Treatment of Myocardial Infarction

TABLE VI

CAUSES OF DEATH IN THE TRIAL AND POST-TRIAL SERIES (REGROUPED)

\begin{tabular}{ll|c|c|c|c|c|c}
\hline & \multicolumn{5}{|c}{ Cause of death } \\
\cline { 2 - 8 } & & Arrhythmias & Other causes & \multicolumn{2}{c}{ Total } \\
\cline { 2 - 8 } & Observed & Expected & Observed & Expected & Observed & Expected \\
\hline Control (85 patients) &. & 20 & 17 & 10 & 8 & 30 & 25 \\
\hline Treated (285 patients) &. & 19 & 59 & 30 & 30 & 49 & 89 \\
\hline
\end{tabular}

* See Table III.

t Derived from the view (Lindsay and Spierkerman, 1964) that arrhythmias are responsible for two-thirds of all deaths in myocardial infarction and the rest of the deaths are due to other causes.

the treated patients of the trial $(16.5 \%)$ and the post-trial series $(17.5 \%)$. This finding assumes added importance as there were proportionately more women than men in the post-trial group and the patients were slightly older when compared with the subjects of the earlier trial, because both these factors tend to affect the prognosis adversely. Six patients who were seriously ill at the time of admission and died within a few hours without receiving the regimen were deliberately included in the final analysis, because it was felt that their exclusion would improve the results of the treatment unjustly. In addition, three deaths which occurred after cessation of therapy were taken into account, because mortality was assessed at the time of discharge from the hospital in order to make the results comparable to those obtained by analysis of 1084 case records.

It has been estimated that the average interval between onset of pain and admission to hospital for patients who took part in the clinical trial was between 11 to 12 hours (Mittra, 1965). This factor is important since the mortality in myocardial infarction falls steeply and progressively from onset for the first $\mathbf{4 8}$ hours. Although no such information is available for patients of the post-trial group, there is no reason to suspect that this interval is significantly different in the two series with its consequent effect on mortality.

Derivation of the expected number of deaths from the standard fatality rate table has proved to be valid in so far as good agreement was achieved between the expected and observed number of deaths among the controls.

Comparison of the expected and observed number of deaths among treated patients of the trial and the post-trial series showed that the reduction in mortality was highly significant in men but not significant in women (Tables III and IV). This consistent difference between the sexes in their response to the treatment poses a problem. It cannot be explained on the basis of any differences in age as this was taken into account when the expected number of deaths was calculated. There is suggestive evidence that the regimen is effective against particular causes of death and that the frequency of various causes differs in the two sexes.

There are good theoretical reasons for believing that the regimen is effective in myocardial infarction, principally because it reduces the number of deaths due to arrhythmias (Sodi-Pallares et al., 1963).

The ratio of $2: 1$ observed between deaths due to arrhythmias and those due to other causes in the control group is in agreement with the generally accepted view (Lindsay and Spiekerman, 1964) that arrhythmias are responsible for two-thirds of all deaths in myocardial infarction. In contrast, the ratio was 2:3 among treated patients, which rather suggests that the deaths due to arrhythmias were prevented by the regimen, as the differences between the two ratios were statistically significant. The same result could be achieved in another way. The expected number of deaths among 285 treated patients was 89 (Table VI). As mentioned before, two-thirds of these (59) were expected to die of an arrhythmia and the remaining 30 patients were expected to die of other causes. In fact, 30 patients did die of "other causes" but only 19 instead of 59 patients died because of an arrhythmia. It can be concluded, therefore, that the efficacy of the regimen lies mainly in prevention of deaths due to arrhythmias, and it does little or nothing to alter the course in patients who die as a result of cardiogenic shock, cardiac failure, and other miscellaneous causes.

It is clear from this analysis (Table $V$ ) that men are more prone to die of an arrhythmia than women, as has been reported previously (White, Edwards, and Dry, 1950; Julian, Valentine, and Miller, 1964). It seems likely, therefore, that the differences in success of the regimen in the two sexes may be accounted for by the difference in proneness to die of an arrhythmia which is specifically prevented by this treatment. 


\section{SUMMARY}

A further 200 patients, with a confirmed diagnosis of myocardial infarction, have been treated with a potassium, insulin, and glucose regimen since the conclusion of a statistically controlled sequential trial of this treatment in June 1965. The results of that trial are confirmed in that identical fatality rates were observed in the post-trial series $(17.5 \%)$ and the treated group of the trial (16.5\%). The treatment is more beneficial to men than women, probably because men are more prone to die of an arrhythmia than women and the regimen is principally effective by causing a reduction in the number of deaths due to arrhythmias.

I am much indebted to Professor G. M. Bull for allowing me to study patients under his care, and for his helpful guidance throughout.

This paper is based on work originally presented to the Association of Physicians of Great Britain and Ireland on April 16, 1966.

\section{REFERENCES}

Julian, D. G., Valentine, P. A., and Miller, G. G. (1964). Disturbances of rate, rhythm and conduction in acute myocardial infarction. Amer. F. Med., 37, 915.

Lindsay, M. I., and Spiekerman, R. E. (1964). Re-evaluation of therapy of acute myocardial infarction. Amer. Heart f., 67, 559.

Mittra, B. (1965). Potassium, glucose, and insulin in treatment of myocardial infarction. Lancet, $2,607$.

Sodi-Pallares, D., Bisteni, A., Medrano, G., De Micheli, A., Ferrer, G., Contreras, R., and Zetina, E. (1963). Effects of the polarizing solution, glucose-insulinpotassium, on the electrocardiogram, electrolytes and morphology of acute experimental myocardial infarction. IVth Int. Congr. Cardiol., Mexico, 1962, Vol. IV-b, p. 226.

White, N. K., Edwards, J. E., and Dry, T. J. (1950). The relationship of the degree of coronary atherosclerosis with age, in men. Circulation, 1, 645. 